\title{
EFEKTIVITAS PATCH SEDERHANA DARI EKSTRAK DAUN KAYU JAWA (Lannea coromandelica (Houtt.) Merr.) TERHADAP PENYEMBUHAN LUKA SAYAT PADA TIKUS (Rattus norvegicus)
}

\section{Nur Faatimah Azzahrah, Abdul Wahid Jamaluddin, Yuko Mulyono Adikurniawan}

\author{
Program Studi Kedokteran Hewan, Universitas Hasanuddin, Makassar \\ Email : abdulwahidjamaluddin@unhas.ac.id
}

\begin{abstract}
Kayu jawa plants are one type of traditional plant that is often used to treat wounds, both internal and external wounds. This plant has been shown to have anti-microbial, anti-oxidant and antiinflammatory effects. Flavonoid compounds have anti-inflammatory activity by protecting erythrocyte membranes against membrane damage causing hemolysis because flavonoids can inhibit inflammatory mediators and free radicals. This study aims to determine the effect of the administration of simple patch from Kayu Jawa leaves extract (Lannea coromandelica Houtt. (Merr.)) On wound healing in white rats (Rattus norvegicus) by looking at the extent of the wound closure and changes in wound morphology compared to controls. This study used a laboratory experimental method with 25 rats as test animals divided into 5 treatment groups, namely 3 treatment groups (simple patch from 2.5\% kayu jawa leaves extract, simple patch from 5\% kayu jawa leaves extract, and simple patch from 10\% kayu jawa leaves extract), 1 positive control group (simple patch from povidone iodine) and 1 negative control group (simple patch without kayu jawa leaves extract). The conclusions of the study was the administration of 5\% Kayu Jawa leaves extract gave the best effect in accelerating wound healing.
\end{abstract}

Key words : Flavonoid, kayu jawa leaves extract, rats, simple patch, wound healin.

\section{PENDAHULUAN}

Tanaman obat merupakan sumber daya biologi (bioresource) utama dalam pengembangan obat herbal, neutraceutical, obat baru, dan starting materials untuk obat semi sintesis atau modern. Pengembangan obat yang berasal dari produk alam telah terbukti berhasil di masa lalu dan teknologi baru telah dikembangkan untuk memperoleh senyawa-senyawa turunan dari berbagai jenis tanaman. ${ }^{1}$ Kelebihan dari pengobatan dengan menggunakan ramuan tumbuhan secara tradisional tersebut ialah tidak adanya efek sampingan yang ditimbulkan seperti yang sering terjadi pada pengobatan kimiawi. ${ }^{2}$

Salah satu tanaman obat tradisional yang banyak dimanfaatkan masyarakat Indonesia, masyarakat Sulawesi Tenggara khususnya adalah Kayu Jawa (Lannea coromandelica (Houtt.) Merr.) atau dalam masyarakat Bugis dikenal dengan sebutan "aju jawa". Tanaman ini adalah salah satu tanaman obat tradisional yang masih sering digunakan oleh masyarakat Bugis sampai sekarang ini karena khasiatnya yang dipercaya sangat ampuh. Biasanya digunakan untuk mengobati luka dalam maupun luka luar. Cara penggunaan tanaman ini berbeda-beda tergantung tujuan penggunaannya, misalnya untuk pengobatan diare atau muntah masyarakat meminum rebusan tanaman ini. Sedangkan untuk mempercepat penyembuhan luka, masyarakat biasanya langsung menggunakan tanaman aju jawa dengan menempelkannya ke bagian luka. ${ }^{3}$ Luka dapat dialami oleh semua orang tak 
Efektivitas patch sederhana dari ekstrak daun kayu jawa (Lannea coromandelica (Houtt.) Merr.) terhadap penyembuhan luka sayat pada tikus (Rattus norvegicus)

terkecuali hewan, baik hewan besar maupun kecil. Aktivitas hewan tersebut dapat terganggu akibat rasa sakit yang diakibatkan oleh luka. Luka menyebabkan bagian dalam tubuh hewan menjadi terpapar dengan bagian luar tubuh, apabila dibiarkan dan tidak diobati dapat timbul infeksi dan penyembuhan luka akan terhambat. ${ }^{4}$ Luka pada kulit, subkutis, dan otot adalah hal yang paling umum dijumpai oleh dokter hewan. Luka bisa disebabkan oleh banyak hal, misalnya gigitan, kecelakaan, luka dari benda tajam, dari tembakan peluru, tongkat, benda logam, dan luka-luka termal. ${ }^{5}$

Selama ini secara turun temurun, masyarakat juga menggunakan herbal dalam penyembuhan luka. Pemberian perlakuan pada luka dapat mempengaruhi proses penyembuhan luka menjadi lebih baik. ${ }^{6}$ Penyembuhan luka merupakan hasil dari proses perbaikan yang jaringan yang terjadi secara kompleks untuk mengganti dan memperbaiki struktur sel dan lapisan jaringan yang hilang maupun rusak. Proses ini terbagi menjadi empat proses yang telah terprogram oleh tubuh yaitu pembekuan darah, inflamasi, perkembangan jaringan baru (proliferasi) dan pembentukan jaringan baru (maturasi).

Dalam usaha mempercepat proses penyembuahan luka maka perlu dicari suatu cara yang bukan hanya membantu proses kesembuhan, tetapi juga praktis, murah, dan yang tidak kalah pentingnya mampu mengurangi bekas luka insisi akibat jahitan. ${ }^{7}$ Penggunaan ekstrak, simplisia, atau bagian dari suatu tanaman dijadikan sebagai obat khasiatnya belum maksimal karena penggunaannya yang kurang praktis jika harus disiapkan dan dioleskan langsung dengan simplisia utuh atau ekstraknya. Oleh karena itu, perlu dikembangkan suatu formula yang dapat memudahkan penggunaannya, sehingga diharapkan akan terjadi perubahan yang lebih efektif dan efisien. ${ }^{8}$ Belakangan penggunaan plester luka cukup populer di dunia medis karena dapat digunakan untuk menutup luka. Plester luka sederhana yang mengandung antiseptik atau antibakteri (lapisan non-adherent dan penyerap) biasanya dipakai untuk menutup luka akut dan lecet. ${ }^{8}$

Penelitian sebelumnya yang dilakukan oleh Wirastuty ${ }^{8}$ menunjukkan bahwa ekstrak kulit batang kayu jawa (Lannea coromandelica (Houtt.) Merr.) dalam bentuk sediaan gel dapat memberikan efek penyembuhan terhadap luka bakar dan pada konsentrasi $3 \%$ memberikan efek paling baik.

Penggunaan empiris secara luas untuk pengobatan dalam masyarakat menggunakan daun tanaman kayu jawa (Lannea coromandelica (Houtt.) Merr.) serta belum adanya publikasi ilmiah tentang efektivitas patch sederhana dari ekstrak daun kayu jawa di Indonesia, menjadi dasar dilakukannya penelitian tentang pengaruh pemberian ekstrak daun Kayu Jawa (Lannea coromandelica (Houtt.) Merr.) dalam bentuk plester luka sebagai alternatif dalam menyembuhkan luka berdasarkan kandungan kimia dalam tumbuhan tersebut.

\section{METODE PENELITIAN}

\section{Alat dan Bahan}

Alat yang digunakan dalam penelitian ini yaitu: kandang tikus, alat bedah minor (nampan stainless still, gunting, dan pinset), timbangan analitik, caliper, clipper, blender, oven simplisia, tabung (wadah), spatula, rotary evaporator, erlenmeyer, sendok, kain hitam, gelas ukur, botol vial, cawan porselin, toples, alumunium foil, plastic wrapping, alat ukur 
Efektivitas patch sederhana dari ekstrak daun kayu jawa (Lannea coromandelica (Houtt.) Merr.) terhadap penyembuhan luka sayat pada tikus (Rattus norvegicus)

kelembaban, kamera dan alat tulis. Bahan penelitian yang digunakan antara lain; tempat minum tikus, masker, daun kayu jawa, etanol $70 \%, \mathrm{NaCl}$, sekam, veet, gloves, spoit, jarum spoit, label, kertas saring, povidone iodine, propilen glikol, tisu, plester luka komersil, bahan formulasi plester (lapisan poliester/adhesive plester, kasa steril, kain perekat dan lem perekat), anastesi (ketamine dan xylasin) dan tikus putih (Rattus norvegicus) galur Sprague dawley.

\section{Prosedur Penelitian}

Pembuatan Patch Sederhana Ekstrak Daun

\section{Kayu Jawa}

Pembuatan ekstrak menggunakan cara maserasi, yaitu dengan cara memasukan simplisia daun kayu jawa kedalam toples kecil, ditambahkan etanol $70 \%$ sebagai pelarut dengan perbandingan 1:3 dan diaduk hingga larut. Selama maserasi sesekali diaduk. Prosedur ini kemudian diulangi 3 kali (remaserasi) hingga filtrat yang didapatkan terlihat jernih. Selanjutnya hasil filtrat disaring menggunakan kertas saring sehingga mendapatkan filtrat, selanjutnya dipekatkan dengan menggunakan alat rotary evaporator pada suhu $70^{\circ} \mathrm{C}$ sampai diperoleh ekstrak etanol kental daun kayu jawa.

Pada patch sederhana dari kelompok perlakuan dilakukan dengan mencampurkan bahan aktif berupa ekstrak daun kayu jawa konsentrasi bertingkat dengan bahan tambahan berupa propilen glikol konsentrasi $5 \%$ dan alkohol $70 \%$ lalu dicampurkan satu sama lain dengan metode pencampuran lalu dimasukkan kedalam tabung (wadah). Propilen glikol digunakan sebagai humektan yang akan mempertahankan kandungan air dalam sediaan sehingga sifat fisik dan stabilitas sediaan selama penyimpanan dapat dipertahankan. ${ }^{9}$ Selain menjaga kestabilan sediaan, secara tidak langsung humektan juga dapat mempertahankan kelembaban kulit sehingga kulit tidak kering. Berdasarkan penelitian yang telah dilakukan oleh Waty ${ }^{10}$, cara pembuatan plester dilakukan dengan menyiapkan potongan kasa yang telah dibentuk dengan ukuran $3 \times 3 \mathrm{~cm}^{2}$ selanjutnya dicelupkan kedalam larutan kental formulasi konsentrasi yang telah dibuat sampai larutan menyerap $100 \%$ ke dalam kasa, setelah itu kasa diperas hingga kering, hal ini dilakukan berulang menggunakan larutan kental yang sama sampai 40 kasa tiap perlakuan. Selanjutnya kasa dikeringkan di suhu ruang selama 24 jam untuk proses pengeringan zat aktif lalu dimasukkan dalam toples yang dibungkus dengan plastic wrapping sampai akan digunakan.

Tabel 1. Formulasi Konsentrasi Kelompok Perlakuan

\begin{tabular}{cccccc}
\hline $\begin{array}{c}\text { Kelompok } \\
\text { Perlakuan }\end{array}$ & $\begin{array}{c}\text { Ekstrak Kental Daun } \\
\text { Kayu Jawa }(\mathbf{m L})\end{array}$ & $\begin{array}{c}\text { Alkohol 70\% } \\
(\mathbf{m L})\end{array}$ & $\begin{array}{c}\text { Propilen } \\
\text { glikol }(\mathbf{m L})\end{array}$ & $\begin{array}{c}\text { Povidone } \\
\text { lodine }(\mathbf{m L})\end{array}$ & $\begin{array}{c}\text { Larutan } \\
\text { Kental }(\mathbf{m L})\end{array}$ \\
\hline $2.5 \%$ & 1.25 & 46.25 & 2.5 & - & 50 \\
$5 \%$ & 2.5 & 45 & 2.5 & - & 50 \\
$10 \%$ & 5 & 42.5 & 2.5 & - & 50 \\
Kontrol (-) & - & 47.5 & 2.5 & - & 50 \\
Kontrol $(+)$ & - & - & - & 50 & 50 \\
\hline
\end{tabular}


Efektivitas patch sederhana dari ekstrak daun kayu jawa (Lannea coromandelica (Houtt.) Merr.) terhadap penyembuhan luka sayat pada tikus (Rattus norvegicus)

\section{Penapisan Fitokimia}

Metabolit sekunder yang diuji secara kualitatif diantaranya: alkaloid, flavonoid, terpenoid, saponin, tanin:

\section{Perlukaan pada Tikus}

Kelompok perlakuan dibagi menjadi 5 kelompok yaitu :

1. Kelompok kontrol negatif sebanyak 5 ekor tikus diberikan patch sederhana tanpa ekstrak daun kayu jawa.

2. Kelompok kontrol positif sebanyak 5 ekor tikus diberikan patch sederhana yang diberi povidone iodine.

3. Kelompok perlakuan I sebanyak 5 ekor tikus diberikan patch sederhana dari ekstrak daun kayu jawa konsentrasi $2.5 \%$.

4. Kelompok perlakuan II sebanyak 5 ekor tikus diberikan patch sederhana dari ekstrak daun kayu jawa konsentrasi 5\%.

5. Kelompok perlakuan III sebanyak 5 ekor tikus diberikan patch sederhana dari ekstrak daun kayu jawa konsentrasi 10\%.

Terlebih dahulu tikus dihilangkan kesadarannya dengan menggunakan kombinasi ketamin $(50 \mathrm{~mL} / \mathrm{kg} \mathrm{BB})$ dan xylasin (5 mL/kg BB) secara intramuscular. Kemudian setiap tikus dicukur menggunakan veet yang diaplikasikan pada bagian punggung tikus lalu dibuat pola persegi dengan panjang dan lebar masing-masing $\pm 2 \mathrm{~cm}$ Tikus selanjutnya dilukai dengan cara dilakukan penyayatan menggunakan gunting tajam-tajam dengan panjang dan lebar $\pm 2 \mathrm{~cm}$ sesuai pola persegi yang telah dibuat sebelumnya sampai fascia. Penyayatan dilakukan di daerah puggung searah dengan os vertebrae.

\section{Perawatan Luka}

Perawatan luka dengan cara dengan cara patch sederhana ditempelkan ke bagian luka setiap dua hari sekali selama 14 hari.

\section{Pengamatan Luka}

Pengamatan patologi anatomi dilakukan pada setiap perlakuan secara deskriptif metode scoring terhadap semua tikus. Kondisi luka diamati setiap dua hari sekali dari hari ke-1 sampai hari ke-14 dengan memperhatikan parameter perbandingan, yaitu penutupan luka (persentase penyembuhan luka) dan morfologi luka (kelembaban luka, warna luka, kecepatan pertumbuhan rambut dan keropeng luka). Luas luka ditentukan dari pengukuran panjang dan lebar luka. Penutupan luka dapat dihitung dengan rumus Morton dalam Ananda dan Ade (2012):

$$
\% \text { persembuhan }=\frac{\mathrm{L} 1-\mathrm{Lx}}{\mathrm{L} 1} \times 100 \%
$$

Keterangan :

$\%$ persembuhan $=$ Persentase persembuhan

$L_{1}=$ Luas luka hari ke-1

$L_{x}=$ Luas luka hari ke- $x$

\section{Analisis Data}

Hasil pengamatan patologi anatomi yang telah dilakukan terhadap semua perlakuan kemudian dianalisis secara statistik deskriptif. Perubahan luas luka dianalisis secara statistik dengan SPSS menggunakan analisis sidik ragam (analysis of variance $=$ anova).

\section{HASIL DAN PEMBAHASAN}

Hasil analisis yang didapatkan yaitu senyawa flavonoid, terpenoid/steroid dan tanin. Hasil penapisan fitokimia ekstrak daun Kayu Jawa dapat diliihat pada tabel 2. Dari berbagai senyawa tersebut, flavonoid diketahui memiliki aktivitas antiinflamasi yang mana bekerja dengan cara menghambat siklooksiginase atau lipooksiginiase dan menghambat akumulasi leukosit di daerah yang terjadi inflamasi. ${ }^{11}$. Dari hasil penapisan fitokimia tersebut, dapat disimpulkan bahwa 
Efektivitas patch sederhana dari ekstrak daun kayu jawa (Lannea coromandelica (Houtt.) Merr.) terhadap penyembuhan luka sayat pada tikus (Rattus norvegicus)

ekstrak daun kayu jawa memiliki aktivitas antiinflamasi. Hal ini juga dapat dikaitkan dengan penelitain yang dilakukan oleh Wirastuty $^{8}$ yang menyatakan bahwa selain senyawa flavonoid yang memiliki aktivitas antiinflamasi, juga terdapat senyawa saponin dan tanin yang berfungsi menurunkan inflamasi dan memiliki efek antimikroba yang dapat mencegah infeksi oleh mikroorganisme.

Tabel 2. Hasil penapisan fitokimia

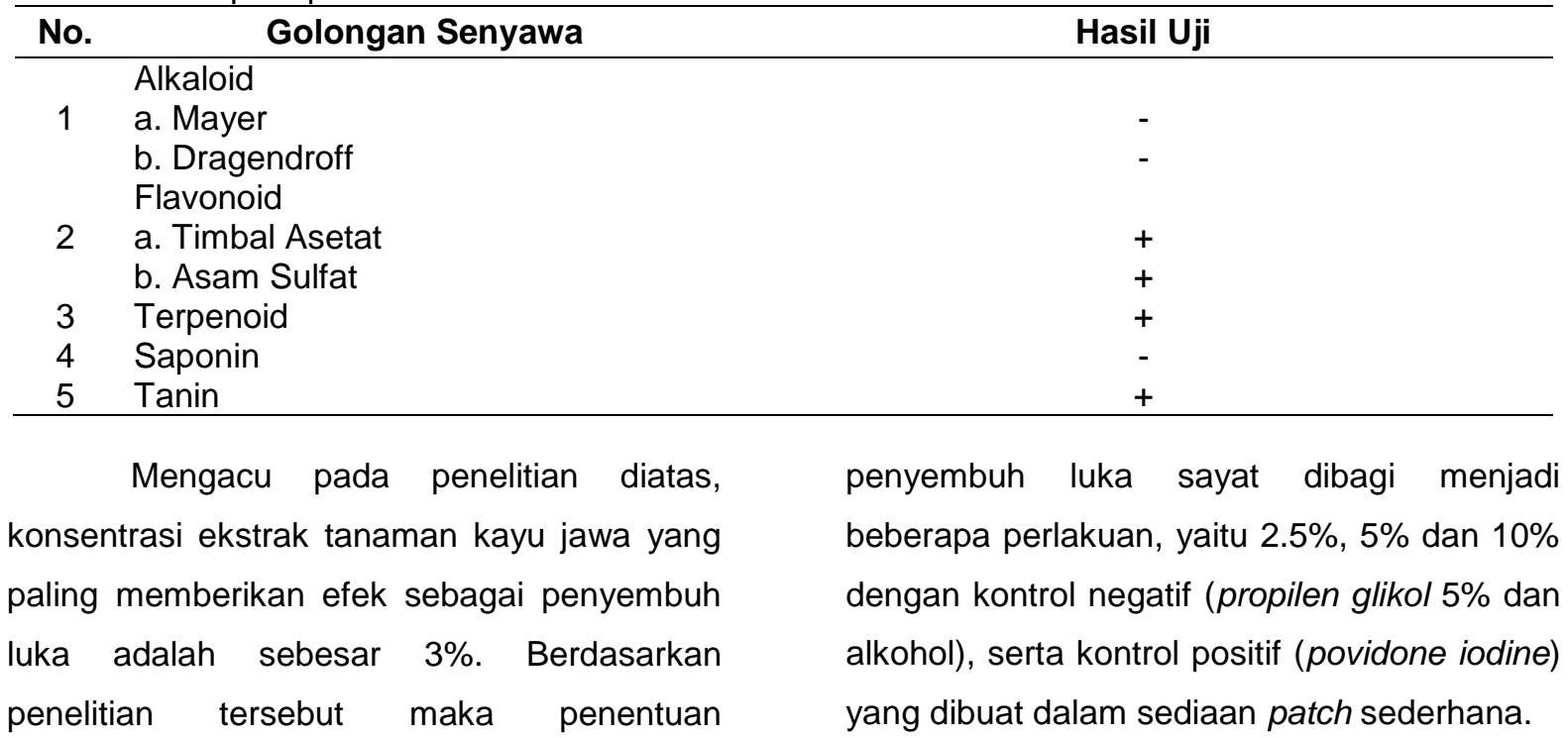

Tabel 3. Tampakan luka sayat

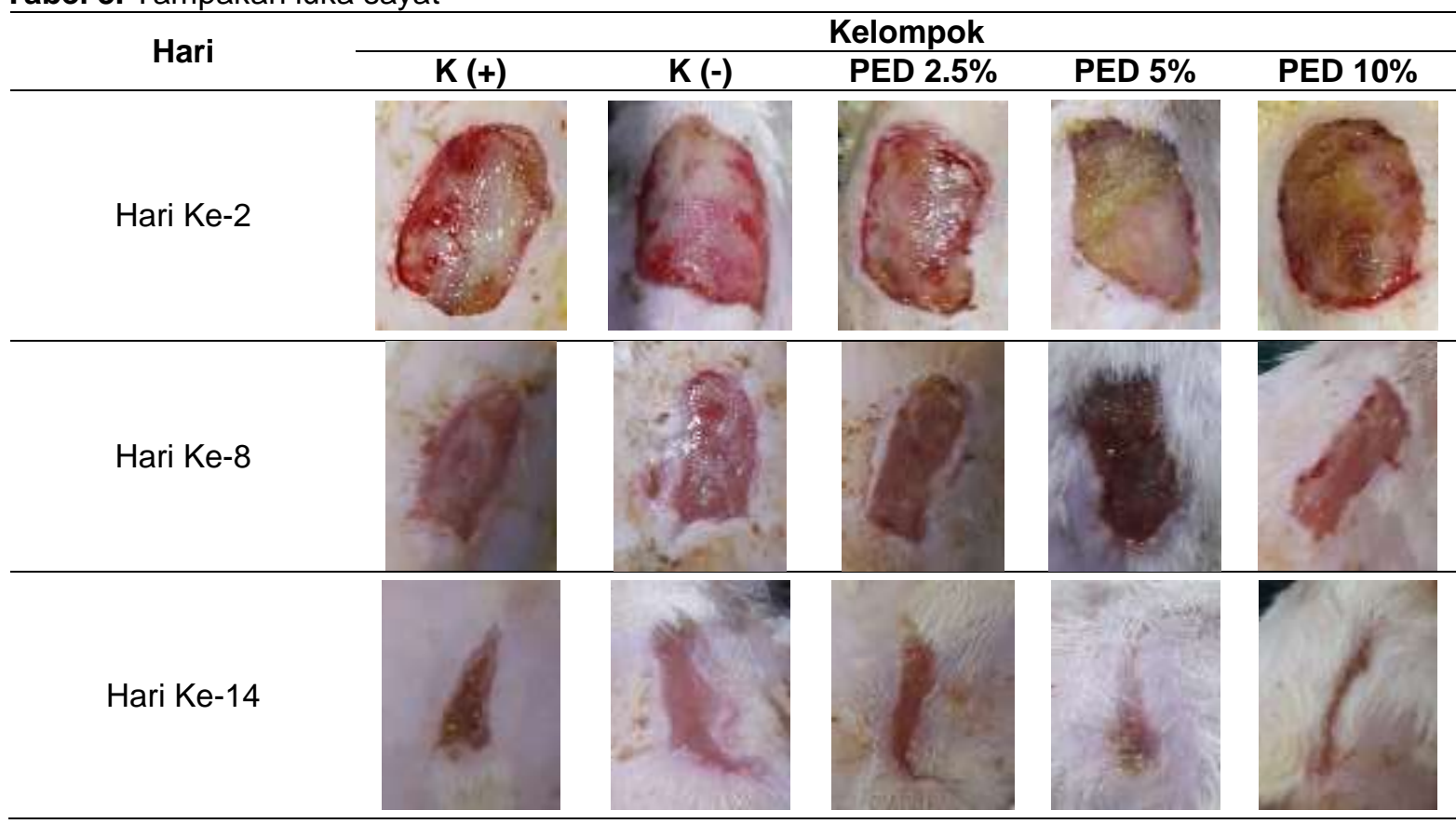

Keterangan:

$\mathrm{K}(+) \quad$ : Kontrol Positif

K(-) : Kontrol Negatif

PED : Patch Ekstrak Daun Kayu Jawa 
Efektivitas patch sederhana dari ekstrak daun kayu jawa (Lannea coromandelica (Houtt.) Merr.) terhadap penyembuhan luka sayat pada tikus (Rattus norvegicus)

Pengamatan patologi anatomi dilakukan dengan memperhatikan parameter perbandingan, yaitu penutupan luka (persentase penutupan luka) dan morfologi luka (kelembaban luka, warna luka dan keropeng luka). Pengamatan dilakukan dengan menggunakan penggaris plastik yang diukur dengan cara mendekatkan penggaris ke pinggir luka tikus yang telah diberi perlakuan.

\section{Persentase Persembuhan Luka}

Pengukuran luas luka yang diukur selama 14 hari dibuat dalam bentuk tabel. Kemudian dari data tersebut dilakukan perhitungan persentase persembuhan luka dengan rumus persembuhan luka. Persentase persembuhan didapatkan dengan membandingan luas luka sebelum perlakuan dengan luas luka setelah perlakuan.

$$
\begin{gathered}
\text { \% persembuhan }=\frac{\mathrm{L} 1-\mathrm{Lx}}{\mathrm{L} 1} \times 100 \% \\
\text { Pengamatan secara deskriptif }
\end{gathered}
$$
mengenai persentase persembuhan luka dimulai dari ke 0-14 diukur tiap dua hari sekali perlakuan. Dari hasil penelitian yang telah dilakukan, diperoleh lama penyembuhan luka dari tiap kelompok relatif sama.

Tabel 4. Persentase persembuhan luka

\begin{tabular}{lccccccccc}
\hline \multirow{2}{*}{ Kelompok } & N & \multicolumn{1}{c}{ Hari Ke-(\%) } \\
\cline { 3 - 10 } & & $\mathbf{0}$ & $\mathbf{2}$ & $\mathbf{4}$ & $\mathbf{6}$ & $\mathbf{8}$ & $\mathbf{1 0}$ & $\mathbf{1 2}$ & $\mathbf{1 4}$ \\
\hline K (+) & 5 & 0 & 10 & 36,25 & 62,5 & 80 & 91,25 & 95 & 95 \\
K (-) & 5 & 0 & 23,5 & 40 & 47,5 & 67,5 & 84,25 & 91,25 & 93,75 \\
PED 2.5\% & 5 & 0 & 23,5 & 47,5 & 67 & 70 & 87,75 & 93,75 & 97,5 \\
PED 5\% & 5 & 0 & 36,25 & 64,25 & 77,25 & 80,75 & 85 & 96,5 & 98,75 \\
PED 10\% & 5 & 0 & 23,5 & 43,75 & 72,5 & 77,5 & 88 & 91,25 & 96,25 \\
\hline
\end{tabular}

Untuk kelompok PED 2.5\% memiliki persentase persembuhan luka pada hari ke-14 yaitu $97.5 \%$ dan tertutup sempurna pada hari ke-16, untuk kelompok perlakuan kelompok PED 5\% memiliki persentase persembuhan luka pada hari ke-14 yaitu $98.75 \%$ dan tertutup sempurna pada hari ke-15, dan untuk kelompok PED 10\% memiliki persentase persembuhan luka pada hari ke-14 yaitu 96.25 $\%$ dan tertutup sempurna pada hari ke-16. Dari hasil penelitian menunjukkan bahwa ekstrak daun kayu jawa dapat mempercepat proses penyembuhan luka. Hal ini disebabkan karena daun kayu jawa mempunyai kandungan senyawa flavonoid yang memiliki aktivitas antiinflamasi dan antioksidan yang dapat menghambat mediator inflamasi dan radikal bebas. Adanya perbedaan persentase persembuhan luka terhadap tikus perlakuan dengan menggunakan patch sederhana ekstrak daun kayu jawa 2.5\%,5\% dan 10\% dikarenakan jumlah ekstrak pada setiap konsentrasi yang berbeda, dimana semakin banyak ekstrak yang ditambahkan maka bahan tambahan yang dimasukkan juga akan berkurang begitupula sebaliknya. Akan tetapi, semakin banyak ekstrak dalam sediaan tidak memastikan akan memberikan efek yang paling baik.

Pada hasil penelitian kelompok perlakuan $\mathrm{K}(+)$ menunjukkan bahwa pemberian patch sederhana dari povidone iodine tidak lebih baik daripada penggunaan patch sederhana dari ekstrak daun kayu jawa konsentrasi bertingkat. Walaupun memiliki persentase persembuhan luka pada hari ke-14 yaitu $95 \%$ dan tertutup sempurna pada hari ke-16. Penggunaan patch sederhana dari povidone iodine pada penelitian ini digunakan sebagai kontrol positif, yang aktifitasnya dalam 
Efektivitas patch sederhana dari ekstrak daun kayu jawa (Lannea coromandelica (Houtt.) Merr.) terhadap penyembuhan luka sayat pada tikus (Rattus norvegicus)

penyembuhan luka terlihat kurang efektif. Hal

ini disebabkan karena luka sayat yang ditutupi dengan patch sederhana dari povidone iodine akan lebih cepat kering karena patch sederhana povidone iodine tidak mengandung bahan tambahan propilen glikol yang dapat menjaga kelembaban patch sederhana sehingga kurang efektif untuk digunakan, hal serupa dikemukakan oleh Bakkara (2012) yang mengatakan bahwa penggunaan povidone iodine kurang begitu efektif, menyebabkan luka tampak tidak sembuh sempurna dan mengurangi kekuatan kulit lokasi luka.

Kelompok $\mathrm{K} \quad(-)$ yang hanya mengandung propilen glikol 5\% dan alkohol $70 \%$, tetapi dari hasil penelitian menunjukkan bahwa persentase persembuhan luka pada $\mathrm{K}$ (-) dan $\mathrm{K}(+)$ tidak berbeda jauh sehingga dapat dipastikan kelompok PED 2.5\%, 5\% dan $10 \%$ memberikan efek penyembuhan luka lebih baik dibandingkan kelompok K (-). Hal ini disebabkan kelompok K (-) tidak mengandung obat atau ekstrak yang memberikan efek mempercepat penyembuhan luka. Kelompok $\mathrm{K}(-)$ hanya mengandung propilen glikol yang menyebabkan luka akan dalam keadaan lembab sehingga akan lama mengering. Luka yang lembab terus menerus akan menyebabkan sulitnya terbentuk jaringan yang baru. Hal tersebut sesuai dengan pendapat Andrie dan Dies (2017) yang menyatakan, kondisi luka yang lembab memfasilitasi pertumbuhan granulasi dan epitelisasi. Perawatan luka pada suasana lembab bermanfaat mencegah dehidrasi jaringan, mempertahankan suhu optimal, mempercepat pemecahan jaringan nekrotik, fase inflamasi, kontraksi luka dan re-epitelisasi, mempercepat angiogenesis, mengurangi pembentukan jaringan parut, dan mengurangi risiko infeksi.

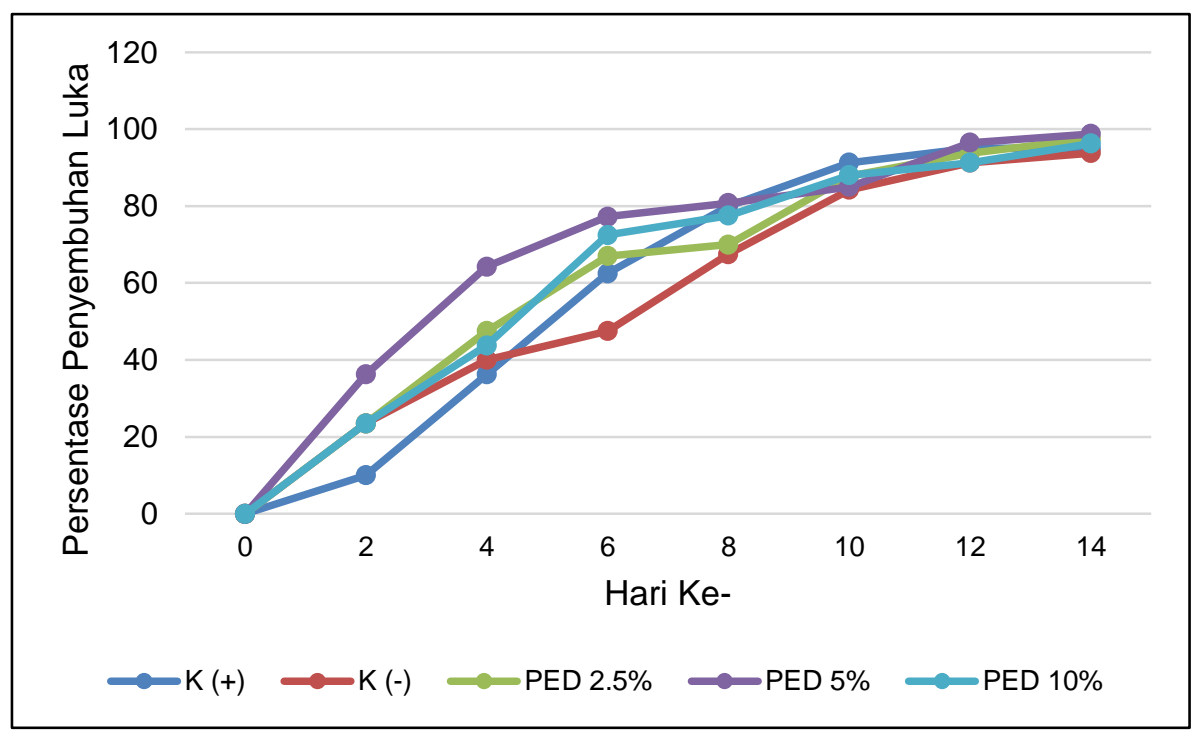

Gambar 1. Grafik persentase persembuhan luka

Berdasarkan gambar 1. menunjukkan kelompok perlakuan patch sederhana dari daun kayu jawa 5\% (PED 5\%) mengalami kenaikan persentase persembuhan luka paling cepat, walaupun pada hari ke-14 persentase persembuhan luka hampir sama. Adanya kandungan senyawa flavonoid dalam ekstrak daun kayu jawa menjadi faktor yang berpengaruh terhadap kecepatan persembuhan luka. 
Efektivitas patch sederhana dari ekstrak daun kayu jawa (Lannea coromandelica (Houtt.) Merr.) terhadap penyembuhan luka sayat pada tikus (Rattus norvegicus)

Selanjutnya dilakukan analisis persentase persembuhan luka menggunakan uji statistik One Way Analysis of Varians (Anova). Berdasarkan hasil pengujian analisis sidik ragam pada Tabel 5 dengan menggunakan uji $\mathrm{F}$ diperoleh nilai 0.036 pada level signifikasi 0,05 . Hal ini menunjukkan nilai $\mathrm{P}(0,01)<0,05$ sehingga $\mathrm{HO}$ ditolak. Hasil uji analisis sidik ragam menunjukkan bahwa ratarata pemberian patch sederhana dari ekstrak daun kayu jawa dengan konsentrasi bertingkat dan kelompok kontrol berpengaruh signifikan terhadap penyembuhan luka sayat pada tikus perlakuan.

Analisis selanjutnya dilakukan uji post hoc dengan metode LSD untuk mengetahui perbedaan antar kelompok. Tabel 6 menunjukkan perhitungan rata-rata persentase persembuhan luka, standar deviasi, dan hasil uji post hoc dengan metode LSD pada hari ke-2, ke-8 dan ke-14.

Tabel 5. Tabel anova persentase persembuhan luka

\begin{tabular}{cccccc}
\hline Sumber Variasi & $\mathbf{d k}$ & Jumlah kuadrat & Rerata Jumlah kuadrat & $\mathbf{F}_{\text {hit }}$ & $\mathbf{F}_{0,05}$ \\
\hline Antargrup & 4 & 442.025 & 110.506 & 3.174 & 0.036 \\
Di dalam grup & 20 & 696.225 & 34.811 & & \\
Total & 24 & 1138.250 & & & \\
\hline
\end{tabular}

Tabel 6. Uji post hoc dengan Isd terhadap rata-rata persentase persembuhan luka serta standar

\begin{tabular}{cccc}
\hline \multirow{2}{*}{ Kelompok } & \multicolumn{3}{c}{ Persentase Penyembuhan Luka (\%) } \\
\cline { 2 - 4 } & Hari Ke-2 & Hari Ke-8 & Hari Ke-14 \\
\hline K $(+)$ & $12.8 \pm 5.4^{\mathrm{a}}$ & $75.1 \pm 4.4^{\mathrm{a}}$ & $96.5 \pm 1.4^{\mathrm{a}}$ \\
K $(-)$ & $17.1 \pm 11.2^{\mathrm{b}}$ & $68.4 \pm 8.4^{\mathrm{b}}$ & $95.1 \pm 2.1^{\mathrm{b}}$ \\
PED 2.5\% & $22 \pm 4.2^{\mathrm{c}}$ & $78.1 \pm 6.8^{\mathrm{b}}$ & $97.6 \pm 0.4^{\mathrm{b}}$ \\
PED 5\% & $39.2 \pm 4.9^{\mathrm{a}, \mathrm{b}, \mathrm{c}}$ & $78.4 \pm 4.7^{\mathrm{b}}$ & $97.6 \pm 1.3^{\mathrm{b}}$ \\
PED 10\% & $22.6 \pm 8.1^{\mathrm{a}}$ & $80.4 \pm 4.1^{\mathrm{b}}$ & $96 \pm 1.6^{\mathrm{c}}$ \\
\hline Nilai P & $\mathbf{0 . 0 0 0}$ & $\mathbf{0 . 0 3 6}$ & $\mathbf{0 . 0 5}$ \\
\hline
\end{tabular}

Uji LSD pada hari ke-2 menujukkan perbedaan yang signifikan antar kelompok $\mathrm{K}$ (+), K (-) dan PED 2.5\% ditandai dengan kode huruf yang berbeda. Sedangkan PED 5\% tidak berbeda nyata dengan kelompok $\mathrm{K}(+), \mathrm{K}(-)$ dan PED $2.5 \%$ ditandai dengan kode huruf yang sama. Sedangkan PED $10 \%$ dan $\mathrm{K}(+)$ tidak memiliki perbedaan yang signifikan ditandai dengan kode huruf yang sama. Pada hari ke-8 menunjukkan perbedaan yang signifikan antar $\mathrm{K}(+)$ dengan $\mathrm{K}(-)$, PED 2.5\%, PED 5\% dan PED 10\% ditandai dengan kode huruf yang berbeda. Sedangkan K(-), PED 2.5\%, PED 5\% dan PED 10\% tidak memiliki perbedaan yang signifikan ditandai dengan kode huruf yang sama. Pada hari ke-14 menunjukkan yang nyata antar $\mathrm{K}(+), \mathrm{K}(-)$, PED $2.5 \%$, PED $5 \%$ dan $10 \%$ ditandai dengan kode huruf yang berbeda. Sedangan K(-), PED 2.5\%, PED 5\% dan PED 10\% tidak memiliki perbedaan yang signifikan ditandai dengan kode huruf yang sama. Kesimpulan uji LSD tersebut bahwa kelompok PED 5\% memiliki pengaruh yang signifikan terhadap perbedaan rata-rata luas luka dengan kelompok $\mathrm{K}(+)$ dan $\mathrm{K}(-) 2.5 \%$ dan $10 \%$. Hal ini berarti terdapat kandungan aktif dari daun kayu jawa di dalam patch sederhana yang berpengaruh terhadap penyembuhan luka sayat pada tikus perlakuan. 
Efektivitas patch sederhana dari ekstrak daun kayu jawa (Lannea coromandelica (Houtt.) Merr.) terhadap penyembuhan luka sayat pada tikus (Rattus norvegicus)

\section{Morfologi Luka}

Hasil parameter kelembaban kulit dapat dilihat Tabel 7 memberikan gambaran variasi kelembaban setiap perlakuan. Luka basah diberikan nilai $(+3)$, luka lembab diberikan nilai $(+2)$ dan luka kering diberikan nilai $(+1)$. Menurut Setyorini (2010), adanya sayatan menyebabkan kulit kehilangan retraksinya sehingga terjadi luka terbuka yang membentuk celah. Sayatan menyebabkan radang karena sayatan tersebut menyebabkan perubahan bentuk pada kapiler menjadi lebih besar. Luka yang terlihat basah disebabkan oleh dilatasi pembuluh darah berkepanjangan sehingga jumlah cairan kompartemen ekstrasel bertambah secara abnormal.

Hasil dari pengamatan menunjukkan bahwa rata-rata pada hari ke-2 semua luka masih dalam keadaan basah. Sedangkan pada pengamatan hari ke-4, rata-rata luka kelompok 1, 4 dan 5 sudah dalam keadaan lembab dan rata-rata luka kelompok 2 dan 3 masih dalam keadaan basah. Pada hari ke-6, rata-rata kelompok 2 masih dalam keadaan basah, sedangkan kelompok 1, 3, 4 dan 5 dalam keadaan lembab. Luka yang masih basah disebabkan saat proses pelepasan patch sederhana dari yang terlalu tergesagesa, sehingga keropeng luka yang harusnya masih menempel menjadi terbuka dan menyebabkan luka menjadi basah kembali. Hari ke-8, rata-rata luka kelompok 1, 2, 3 dan 5 dalam keadaan lembab dan luka kelompok 4 telah menjadi luka kering. Pada hari ke-10, kebanyakan luka kelompok 5 telah menjadi luka kering dan rata-rata luka kelompok 1, 2 dan 3 masih dalam keadaan lembab sampai hari ke-12. Pada hari ke-14, rata-rata luka kelompok 1, 3, 4 dan 5 telah menjadi luka kering dan kebanyakan luka kelompok 2 masih dalam keadaan lembab. Luka mengering dan membentuk keropeng dihari selanjutnya hingga luka menutup dan keropeng terlepas dari luka. Pada fase ini juga akan terjadi angiogenesis yaitu suatu proses kapiler-kapiler pembuluh darah yang baru tumbuh atau pembentukan jaringan baru (granulasi tissue). ${ }^{12}$

Luka yang telah mengering kemudian menebal membentuk keropeng pada permukaan luka. Perbaikan jaringan terus terjadi sampai membentuk jaringan kulit yang baru pada luka yang tertutup oleh keropeng. Pada saat luka menutup sempurna, keropeng akan tertarik dan terlepas dari luka sehingga nampak jaringan kulit yang baru. Keropeng yang terlepas setelah luka menutup diikuti dengan tumbuhnya rambut pada jaringan kulit yang baru.

Tabel 7. Skoring perubahan kelembaban luka

\begin{tabular}{ccccccccc}
\hline \multirow{2}{*}{ Kelompok } & \multicolumn{10}{c}{ Hari Ke- } \\
\cline { 2 - 9 } & $\mathbf{0}$ & $\mathbf{2}$ & $\mathbf{4}$ & $\mathbf{6}$ & $\mathbf{8}$ & $\mathbf{1 0}$ & $\mathbf{1 2}$ & $\mathbf{1 4}$ \\
\hline K (+) & +3 & +3 & +2 & +2 & +2 & +2 & +2 & +1 \\
K (-) & +3 & +3 & +3 & +3 & +2 & +2 & +2 & +2 \\
PED 2,5\% & +3 & +3 & +3 & +2 & +2 & +2 & +2 & +1 \\
PED 5\% & +3 & +3 & +2 & +2 & +1 & +1 & +1 & +1 \\
PED 10\% & +3 & +3 & +2 & +2 & +2 & +1 & +1 & +1 \\
\hline
\end{tabular}

Keterangan :

K : Kontrol

PED : patch sederhana dari Ekstrak Daun kayu jawa.

+3 : Luka Basah

+2 : Luka Lembab

+1 : Luka Kering 
Efektivitas patch sederhana dari ekstrak daun kayu jawa (Lannea coromandelica (Houtt.) Merr.) terhadap penyembuhan luka sayat pada tikus (Rattus norvegicus)

Dari hasil pengamatan Tabel 8 menunjukkan bahwa keropeng muncul rata-rata pada hari ke4 dan telah kering sempurna dengan keropeng yang menutup dengan jelas pada hari ke-8 dan ke-10. Keropeng akan menebal hingga terbentuk jaringan baru dan akan terlepas sendiri ketika proses angiogenesis (pembentukan jaringan baru) selesai. Lepasnya keropeng akan memberikan perubahan drastis pada luka, mulai dari warna, kelembaban dan ukuran luka. Rata-rata keropeng terbuka di hari ke-14.

Tabel 8. Skoring perubahan keropeng luka

\begin{tabular}{ccccccccc}
\hline \multirow{2}{*}{ Kelompok } & \multicolumn{10}{c}{ Hari Ke- } \\
\cline { 2 - 9 } & $\mathbf{0}$ & $\mathbf{2}$ & $\mathbf{4}$ & $\mathbf{6}$ & $\mathbf{8}$ & $\mathbf{1 0}$ & $\mathbf{1 2}$ & $\mathbf{1 4}$ \\
\hline K (+) & +4 & +4 & +3 & +3 & +2 & +1 & +1 & +1 \\
K (-) & +4 & +3 & +3 & +2 & +2 & +2 & +2 & +1 \\
PED 2,5\% & +4 & +3 & +3 & +3 & +2 & +2 & +2 & +1 \\
PED 5\% & +4 & +3 & +3 & +2 & +1 & +1 & +1 & +1 \\
PED 10\% & +4 & +4 & +3 & +3 & +2 & +2 & +2 & +1 \\
\hline
\end{tabular}

Keterangan :

K : Kontrol,

PED : patch sederhana dari Ekstrak Daun kayu jawa.

+4 : Keropeng belum terbentuk

+3 : Keropeng tipis dan menutup sebagian luka

+2 : Keropeng tebal dan menutup seluruh luka

+1 : Keropeng terbuka dan terbentuk jaringan utuh/intact

Hasil dari pengamatan warna luka ditunjukkan pada Tabel 9 Luka berwarna merah segar pada hari ke-1 rata-rata pada semua perlakuan hingga hari ke-2 diberi skor +4. Rata-rata kelompok 1, 2, 3 dan 5 masih berwarna merah segar, sedangkan kebanyakan luka kelompok 4 sudah berubah menjadi merah pucat. Pada hari ke-4, kebanyakan luka kelompok 3 masih berwarna merah segar dan luka kelompok lainnya berwarna merah pucat. Pada hari ke-6,

kebanyakan luka kelompok 4 berubah warna menjadi merah kecoklatan sampai hari ke-10, sedangkan rata-rata luka kelompok lainnya masih berwarna merah pucat. Pada hari ke12, kebanyakan luka kelompok 4 berubah warna menjadi merah rose sampai hari ke-14, sedangkan rata-rata luka kelompok lainnya berubah menjadi merah kecoklatan. Pada hari ke-14, rata-rata semua luka sudah berubah warna menjadi merah rose.

Tabel 9. Skoring perubahan warna luka

\begin{tabular}{cccccccccc}
\hline \multirow{2}{*}{ Kelompok } & \multicolumn{10}{c}{ Hari Ke- } \\
\cline { 2 - 32 } & $\mathbf{0}$ & $\mathbf{2}$ & $\mathbf{4}$ & $\mathbf{6}$ & $\mathbf{8}$ & $\mathbf{1 0}$ & $\mathbf{1 2}$ & $\mathbf{1 4}$ \\
\hline K (+) & +4 & +4 & +3 & +3 & +3 & +3 & +2 & +1 \\
K (-) & +4 & +4 & +3 & +3 & +3 & +3 & +2 & +1 \\
PED 2,5\% & +4 & +4 & +4 & +3 & +2 & +2 & +2 & +1 \\
PED 5\% & +4 & +3 & +3 & +2 & +2 & +2 & +1 & +1 \\
PED 10\% & +4 & +4 & +3 & +3 & +3 & +2 & +2 & +1 \\
\hline
\end{tabular}

\begin{tabular}{ll}
\hline Keterangan : \\
K $\quad$ : Kontrol \\
PED $:$ patch sederhana dari Ekstrak Daun kayu jawa. \\
$+4 \quad:$ Merah Segar \\
$+3 \quad:$ Merah Pucat \\
$+2 \quad:$ Merah Kecoklatan \\
$+1 \quad:$ Merah rose
\end{tabular}


Efektivitas patch sederhana dari ekstrak daun kayu jawa (Lannea coromandelica (Houtt.) Merr.) terhadap penyembuhan luka sayat pada tikus (Rattus norvegicus)

Berdasarkan pengamatan patologi anatomi yang telah dilakukan, menunjukkan bahwa PED 2.5\%, PED 10\%, K(+) dan K(-) dapat mempertahankan kelembaban hingga hari ke-8 sedangkan PED 5\% sudah dalam kondisi kering. Hal ini menunjukkan bahwa propilen glikol dapat mempertahankan kelembaban dan kering pada sediaan yang menyebabkan sel fibroblast dapat berproliferasi ke dalam luka sehingga dapat terbentuk jaringan baru. Pada Tabel 9 menunjukkan bahwa PED 2.5\%, PED 10\%, $\mathrm{K}(+)$ dan $\mathrm{K}(-)$ keropeng masih tebal dan menutup seluruh luka hingga hari ke-8 sedangkan PED 5\% keropeng sudah terbuka dan terbentuk jaringan yang baru. Dengan terbentuknya keropeng hal ini menunjukkan adanya jaringan mulai terbentuk sebagai usaha mempercepat penyembuhan luka. Oleh karena itu, dapat disimpulkan bahwa PED 5\% dapat mempercepat penyembuhan luka sayat pada tikus karena perbandingan antara bahan aktif dan bahan tambahan yang setara.

Pada PED $2.5 \%$ terlihat bahwa campuran ekstrak daun kayu jawa dan propilen glikol kurang menyatu dikarenakan volume ekstrak daun kayu yang diberikan lebih sedikit. Pada PED 5\% terlihat bahwa campuran sediaannya lebih rata karena volume ekstrak daun kayu jawa dan propilen glikolnya yang sama sehingga pencampurannya akan sangat menyatu. Dan pada PED $10 \%$ sangat terlihat jelas perbedaan dari kedua sediaan patch sederhana sebelumnya, karena jumlah ekstrak pada konsentrasi ini otomatis lebih banyak sehingga propilen glikol tidak dapat menyatu sempurna dengan ekstrak daun kayu jawa sehingga sediaan PED 10\% terlihat hanya dipenuhi ekstrak daun kayu jawa.
PED 5\% memiliki volume ekstrak daun kayu jawa dan propilen glikol yang sama sehingga pencampurannya akan kental merata. Kekentalan pada larutan dapat menjadi barier fisik luka dari lingkungan sekitar dan menciptakan lingkungan yang lembab. Keadaan yang lembab dapat membantu mempercepat pertumbuhan bakteri, sehingga proses penyembuhan luka akan terhambat dengan adanya infeksi bakteri. Sehingga, apabila semakin banyak volume ekstrak dalam larutan maka volume bahan tambahan akan berkurang begitupula sebaliknya, hal ini yang akan menyebabkan luka akan lebih lama mengalami kelembaban ataupun lebih cepat kering. ${ }^{13}$

Selain faktor kelembaban, kandungan flavonoid yang terkandung dalam ekstrak daun kayu jawa juga sangat berpegaruh terhadap proses penyembuhan luka. PED 5\% memberikan efek yang lebih cepat dibandingkan dengan PED $2.5 \%$ dan PED $10 \%$. Hal ini mungkin menunjukkan bahwa kandungan ekstrak yang banyak tidak menentukan akan memberikan efek penyembuhan luka yang paling cepat. Kadar flavonoid akan mengalami penurunan pada konsentrasi tinggi. Hal tersebut disebabkan oleh peningkatan kepekatan dari larutan yang mengakibatkan penurunan aktivitas antioksidannya sehingga PED $5 \%$ yang memiliki konentrasi ektrak dan konsentrasi bahan tambahan yang seimbang dapat mempercepat proses penyembuhan luka. ${ }^{14}$

Hasil dari penelitian ini dapat dipengaruhi keterbatasan dan kesalahan dari peneliti. Pertama, pengukuran luas luka yang tidak dilakukan setiap hari, sehingga selisih ukuran luas luka setiap harinya tidak jelas. Kedua, pengukuran luas luka yang tidak 
Efektivitas patch sederhana dari ekstrak daun kayu jawa (Lannea coromandelica (Houtt.) Merr.) terhadap penyembuhan luka sayat pada tikus (Rattus norvegicus)

menggunakan penggaris jangka sorong, sehingga akurasi dari ukuran luka tidak terlihat. Ketiga, kesalahan terjadi dari peneliti yang kurang teliti dalam melaksanakan setiap tahap selama proses penelitian berlangsung.

\section{KESIMPULAN}

Berdasarkan penelitian yang tekah dilakukan, dapat disimpulkan bahwa pemberian patch sederhana dari ekstrak daun kayu jawa konsentrasi 2.5\%, 5\% dan 10\% dapat mempercepat proses penyembuhan luka sayat pada tikus dan pemberian patch sederhana dari ekstrak daun kayu jawa dengan konsentrasi 5\% menunjukkan efek penyembuhan luka lebih cepat diantara konsentrasi lain.

\section{DAFTAR PUSTAKA}

1. Mulyaningsih S, Darmawan E. Efek Anti Artritis Pisang Ambon (Musa Paradisiaca Sapientum L.) dan Lidah Buaya (Aloe Vera L.) Terhadap Adjuvant-Induced Arthritic Pada Tikus. Biodiversitas. 2006;7(3):273-277.

2. Thomas ANS. Tanaman Obat Tradisional. Jakarta: Penerbit Kanisius, 1992.

3. Rahayu S, Diah S dan P Suhardjono. Pemanfaatan Tumbuhan Obat secara Tradisional oleh Masyarakat Lokal di Pulau Wawoni, Sulawesi Tenggara. Jurnal Biodiversitas. 2006;7(3): 245-250.

4. Sjamsuhidajat $\mathrm{R}$ dan De Jong W. Buku Ajar IImu Bedah Edisi 2. Jakarta : EGC,2005.

5. Pavletic MM. Atlas Of Small Animal Wound Management And Reconstructive Surgery Third Edition. lowa : W.B Saunders Comapany,2010.

6. Derrick. Aktivitas penyembuhan luka rimpang kunyit (Curcuma Longa Linn.) terhadap luka insisi pada mencit SwissWebster jantan dewasa (Skripsi).
Bandung: Fakultas Kedokteran Universitas Kristen Maranatha, 2015.

7. Mustika DG, Kardena IM, Pemayun IGAGP. Efektivitas Plester Luka pada Aplikasi Penutup Luka Insisi Pasca Operasi. Buletin Veteriner Udayana. 2015;7(2):137-145.

8. Wirastuty RY. Uji efektivitas gel ekstrak etanol kulit batang kayu jawa (Lannea coromandelica) pada kelinci (Oryctolagus cuniculus) sebagai obat penyembuhan luka bakar. Journal Of Pharmaceutical Science And Herbal Technology.2016;1(1):32-35.

9. Allen LVJr. The Art, Science, and Technology of Pharmaceutical Compounding. 2nd Ed. Washington, D. C.: American Pharmaceutical Association, 2002.

10. Waty HR. Modifikasi kitosan pada aplikasi plester luka berbasis kitosan (Chitoplast) sebagai transdermal patch antibakteri (Skripsi). Bogor: Departemen Teknologi Hasil Perairan Fakultas Perikanan Dan IImu Kelautan Institut Pertanian Bogor, 2012.

11. Manurung NRM, Sumiwi SA. Aktivitas antiinflamasi berbagai tanaman diduga berasal berasal dari flavonoid. Farmaka Suplemen.2017;14(2):111-122.

12. Qomariah S. Efektivitas salep ekstrak batang patah tulang (Euphorbia tirucalli) pada penyembuhan luka sayat tikus putih (Rattus norvegicus)(Skripsi). Semarang: Universitas Negri Semarang, 2014.

13. Kumari $S$, Harjai $K$ and Chhibber $S$. Topical Treatment of Klebsiella Pneumoniae B5055 Induced Burn Wound Infection in Mice Using Natural Product. J Infect Dev Ctries. 2010;4(6):367-377.

14. Nijveldt RJ, Van Nood E, Van Hoorn DE, Boelens PG, Van Norren K, Van Leeuwen PA. Flavonoids: a review of probable mechanisms of action and potential applications. Am J Clin Nutr.2001;74(4):418-25. 